\title{
Drive unit characteristics of a completely electrical passenger aircraft
}

Research Article

Jean-Marc Fąfara*

Department of Mechanics, Machines and Energy Processes, Faculty of Mechanical and Power Engineering, Wroclaw University of Science and Technology, Wroclaw, Poland

Received February 19, 2020; Accepted June 05, 2020

Abstract: Aviation has, over the years, become an inseparable element of human life. Airplanes are very commonly used for various tasks, such as transport of passengers and goods, military attack and defence, rescue, recreation and so on. In spite of the many advantages of aviation, one cannot ignore its disadvantages. The most important disadvantages of aviation are the emissions that cause atmospheric pollution and noise. Additionally, one should remember about the decreasing stocks of non-renewable fuels. These drawbacks affect human health and the natural environment. Therefore, a good alternative to conventional drive units in aircraft may turn out to be electric drive units in the near future. The aim of this article is to check the extent to which today's knowledge and technology allow the use of electric drive units instead of conventional aircraft drive units. This article presents the concept of electric aircraft, from the electric drive unit to its power supply system. The feasibility of designing an electric jet drive unit for a passenger aircraft was analysed based on the performances of PZL 104 Wilga 35 and Boeing B787 Dreamliner.

Keywords: aircraft • electric drive unit • fuel cells • all-electric aircraft • green aviation

\section{Introduction}

Ever since humans came into existence, they have always been moving. In the past, people were moving looking for fertile ground, but today, they are looking for job, relaxation and so on. With the development of humans and their techniques, the ways of moving have changed, starting from the human legs to the technologically advanced aircraft. In today's world, the aircraft is one of the frequently used ways of transport. Modern civil aircraft are equipped with turbojet engines, which allow them to fly. Modern passenger aircraft provide fast and effective transport; however, they carry a number of disadvantages, such as consumption of non-renewable fuels, generation of atmospheric pollutants, represented in Figure 1 (Climate Change Authority, 2014) and acoustic pollution, illustrated in Figure 2 (Eco-Healthy Child Care, 2016). Therefore, aeronautical engineers are looking for new solutions in the conception of aircraft, proceeding to more electric aircraft, even to all-electric aircraft.

To understand the idea of the all-electric aircraft, we have to return to the beginning of aviation. In the first years of aviation, the aircraft had small sizes; to control these machines, small rudders were used. The small sizes of the rudders and low flight velocity allowed the pilot to move the rudders by a simple control system that could be manipulated by just using his/her muscles. The control system was based on a simple mechanical displacement system, transforming the pilot's moves into rudder moves. Then, with the evolution of aircraft sizes and the increase in flight velocities, the forces needed to move rudders became too significant to be moved by a simple control system using just human muscle; thus evolved the hydraulic actuators. Hydraulic actuators move the rudders by using the hydraulic power generated by hydraulic pumps powered by the aircraft engines. It was an interesting idea, but there were a problem with this solution: the weight of the hydraulic pipes was significant. To solve this problem, the idea of powering the hydraulic actuators by a reduced hydraulic pump mounted next 


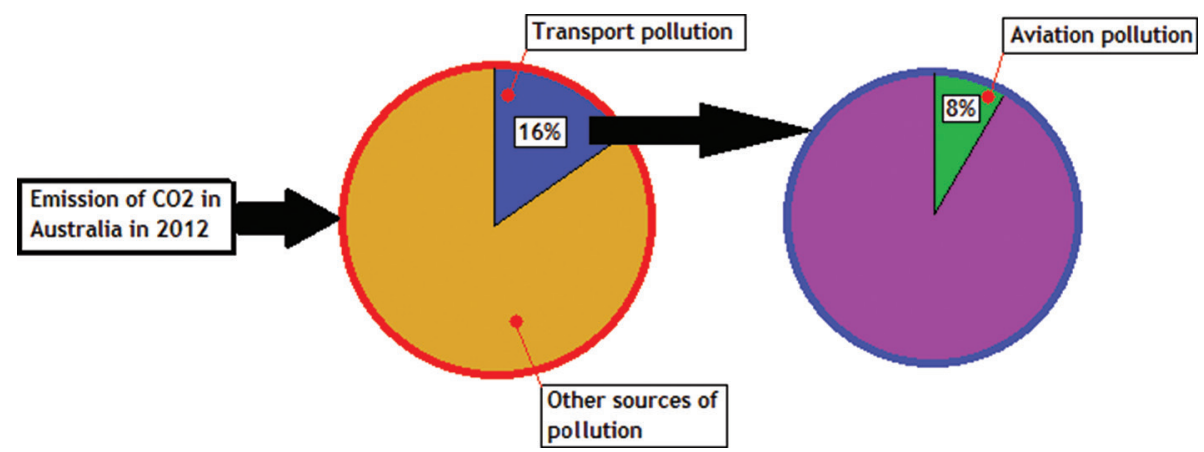

Fig. 1. Graphic representation of the aviation emission of carbon dioxide, as the percentage emission against the background of other modes of transport, considering the example of Australia.

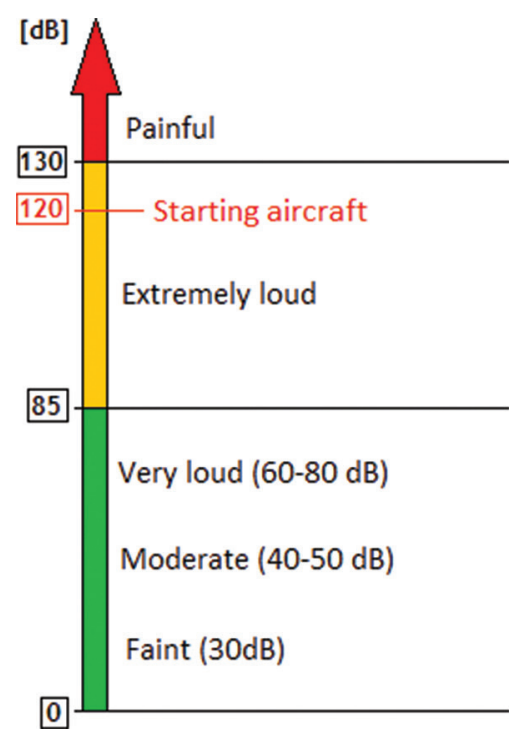

Fig. 2. The noise pollution due to aviation.

to the actuator evolved. To power the pumps, electric engines are used, powered by generators mounted on the engines. This solution was applied, for example to replace the emergency hydraulic system. Thus, the emergency hydraulic pipes were replaced by light electric wires. This provoked an increase in the electric power generated on-board the aircraft, apart from hydraulic power; we are talking about 'more-electric aircraft' (MEA) (Maré and Fu, 2017). An interesting example of MEA is the Airbus A380, the first flight of which was in 2005. The development of MEA provoked the need for designing new kinds of electric on-board systems with more capacitive batteries (Tariq et al., 2017; Yang et al., 2015). The next stage in the concept of green aviation is to replace all the power systems with just electric systems, even replacing the traditional engines by electric engines. Thus, an aircraft could be powered just by electric power. To generate the electric power, hydrogen fuel cells could be used. The advantage of this solution would be significant reduction of noise and atmospheric pollution. It sounds very optimistic, but today's technology has not yet been able to create the engine and power supply for building an effective all-electric aircraft.

Much effort has been taken to make aviation less harmful for humans and the environment; however, according to the French authority on airport noise control (Autorité de Contrôle des Nuisances Sonores Aéroportuaires [ACNUSA] or Airport Pollution Control Authority), conventional jet engines are responsible for a large amount of atmospheric pollution. Jet engines generate large quantities of sulphur dioxide $\left(\mathrm{SO}_{2}\right)$, nitrogen oxides $\left(\mathrm{NO}_{x}\right)$, ozone $\left(\mathrm{O}_{3}\right)$, and heavy metals. Sulphur dioxide is responsible for acid rains and degradation of buildings, and it may provoke irritation of the mucous membranes and respiratory tract. The nitrogen oxides are responsible for acid rains, ozone formation and the greenhouse effect and may be a source of bronchial irritation, in addition to 
promoting lung infections in children and increasing the frequency and severity of asthmatic crises. Ozone has a harmful effect on vegetation, contributes indirectly to the greenhouse effect and may provoke cough, alterations in the lung and eye irritation. The heavy metals affect the nervous system, kidney, liver and respiratory functions. Of course, other harmful substances are generated by conventional engines, such as the hydrocarbons, carbon monoxide ( $\mathrm{CO}$ ) and volatile organic compounds. All these substances have a significant harmful effect on humans and the environment.

The solution that could reduce the negative aspects of aviation is the building of all-electric aircraft. This solution is not possible in the current state of art used to build aircraft. All-electric aircraft would not emit atmospheric pollutants, not use non-renewable fuel for the generation of thrust, and would limit noise pollution. It sounds very optimistic, but today's technology is not yet capable of creating engine and power supply for the effective building of an all-electric aircraft.

\section{All-electric aircraft's structure}

An all-electric aircraft would be similar to conventional aircraft but also have some new elements. The similarity with conventional turbojet engine is that they use the same hydrodynamic phenomenon to generate the thrust (Dzierżanowski et al., 1983). This hydrodynamic effect consists of generating the thrust as a result of acceleration of the stream of air mass flowing through the engine. In conventional aircraft, the air mass is accelerated by the working of the compressor, the combustor and the turbine, or sometimes additionally by a fan, located before the turbojet engine (turbofan jet engine). Similarly to a turbofan jet engine, in an all-electric jet engine, the acceleration of the airflow mass would be achieved by a fan. The difference appears in the method of powering the fan; in conventional turbofan jet engine, the fan is powered by the interior turbojet engine, whereas in the all-electric jet engine, the fan would be powered by an electric drive (Figure 3). This main difference renders indispensable the rebuilding of the energy systems and the power supply of the all-electric aircraft. Moreover, an electric engine could be equipped with a diagnostic system, preventing engine failure during flight, for example by using the axial flux (Wolkiewicz and Skowron, 2017).

The control of the electric jet engine is possible by setting the control signals to the electric motor's controller. The controller, reading the control signal, would change the engine's work range, and as a result, would control the thrust generated by the electric jet engine. The engine controller would be coupled with the commands of the crew, as well as with an autopilot.

Considering an all-electric aircraft, it is important to notice that generating pneumatic and hydraulic energy by aggregates mounted on the jet engine would not be possible. The inability of using these types of energy may be resolved by two technical options. The first one consists of replacing all the power devices using pneumatic and hydraulic energy by power devices that can themselves generate their hydraulic or pneumatic energy by using small electric pumps and compressors. The second one consists of using power devices achieving the same
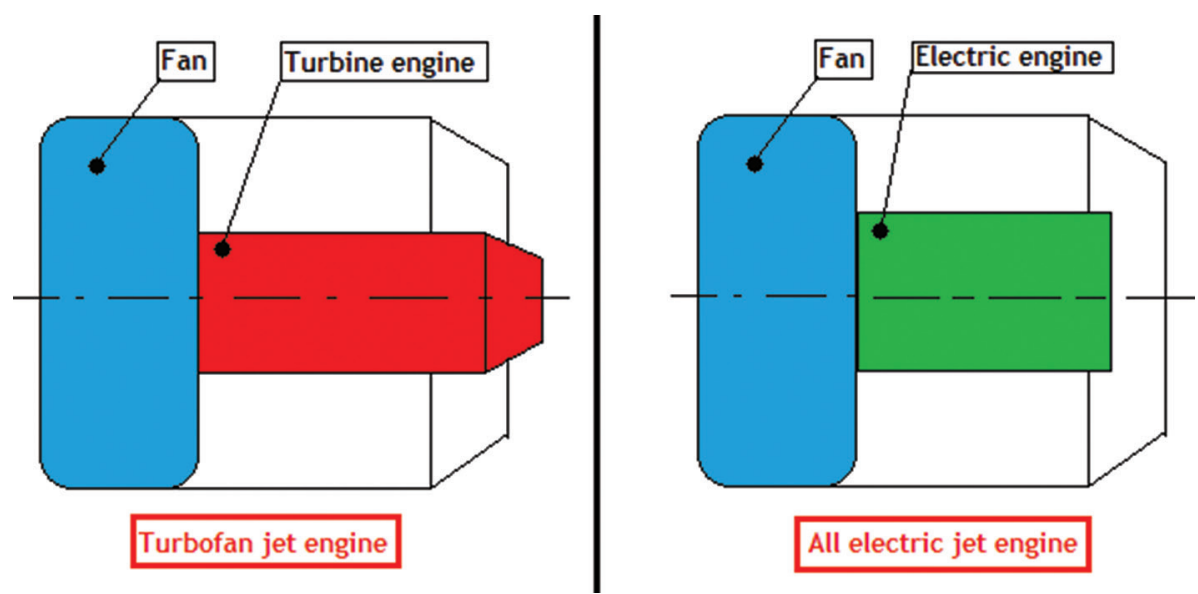

Fig. 3. Comparison of conventional and all-electric aircraft engines. 
functions as the pneumatic/hydraulic power devices, but by just using electric energy. As an example of the first method, it is possible to power a hydraulic actuator by a reduced electrical hydraulic pump mounted near this actuator. An example of the second method is the use of a mechanical actuator instead of a hydraulic or pneumatic actuator. Both methods have the same target, which is to achieve the same functions as the original power devices, but by just using electric energy. The remaining on-board electrical equipment is not a problem, because it runs on electric energy, similar to the other on-board equipment and jet engines.

By performing changes to the aircraft, as described above, all devices of the airplane and its propulsion will be powered just by electric energy.

Then, all the electric equipment will be powered by a special power bus, providing electricity with the needed parameters for each device. Electrical power supplies (batteries or fuel cells) are built with a combination of cells. The electrical power supplies are made of a number of cells, which are partly connected in series and partly in parallel. This permits the design of an electrical power supply with several current outputs of different parameters, by connections taken from among cells. All power buses would finally converge at one point; this point is the beginning of the power bus, connected directly to the power supply.

In conventional passenger aircraft, the on-board source of energy is the fuel, while in all-electric aircraft, the source of energy will be devices storing electrical energy (battery) or devices generating electrical energy using another type of fuel (e.g. hydrogen). The batteries are characterised by easy accessibility, long charging time and low energy density. Furthermore, in the discharge stage, the voltage is decreasing, which can disturb the working of electrical equipment. The solution to this disadvantage may be the application of fuel cells. These devices convert fuel energy (e.g. from hydrogen) into electrical energy. The fuel cells are characterised by the variety of construction solutions available and the types of fuel used. For example, the solid oxygen fuel cells (SOFCs) generate electrical energy using oxygen (contained in the air) and hydrogen.

As a result of electricity production, water vapour and heat are generated. The heat can be treated as 'pollution' and be rejected to the exterior of the aircraft or be used to power the anti-icing system. The voltage characteristic of fuel cells is also interesting; it is stable during the entire working period. Furthermore, the energy carrier is hydrogen. It means that the power generating time of fuel cells is dependent on just the hydrogen quantity taken on board the aircraft. The use of hydrogen is positive not only because only water vapour is generated as pollutant but also because it is convenient: the refuelling of the aircraft is similar to the refuelling of a conventional aircraft in terms of the method and the duration. This is another characteristic that makes the fuel cells more interesting than batteries. Unfortunately, fuel cells have disadvantages also, such as high device weight and high prices of manufacturing. A more-explicit comparison of the weight between batteries and fuel cells will be carried out during the case study.

A scheme showing the architecture of an all-electric passenger aircraft is shown below (Figure 4).

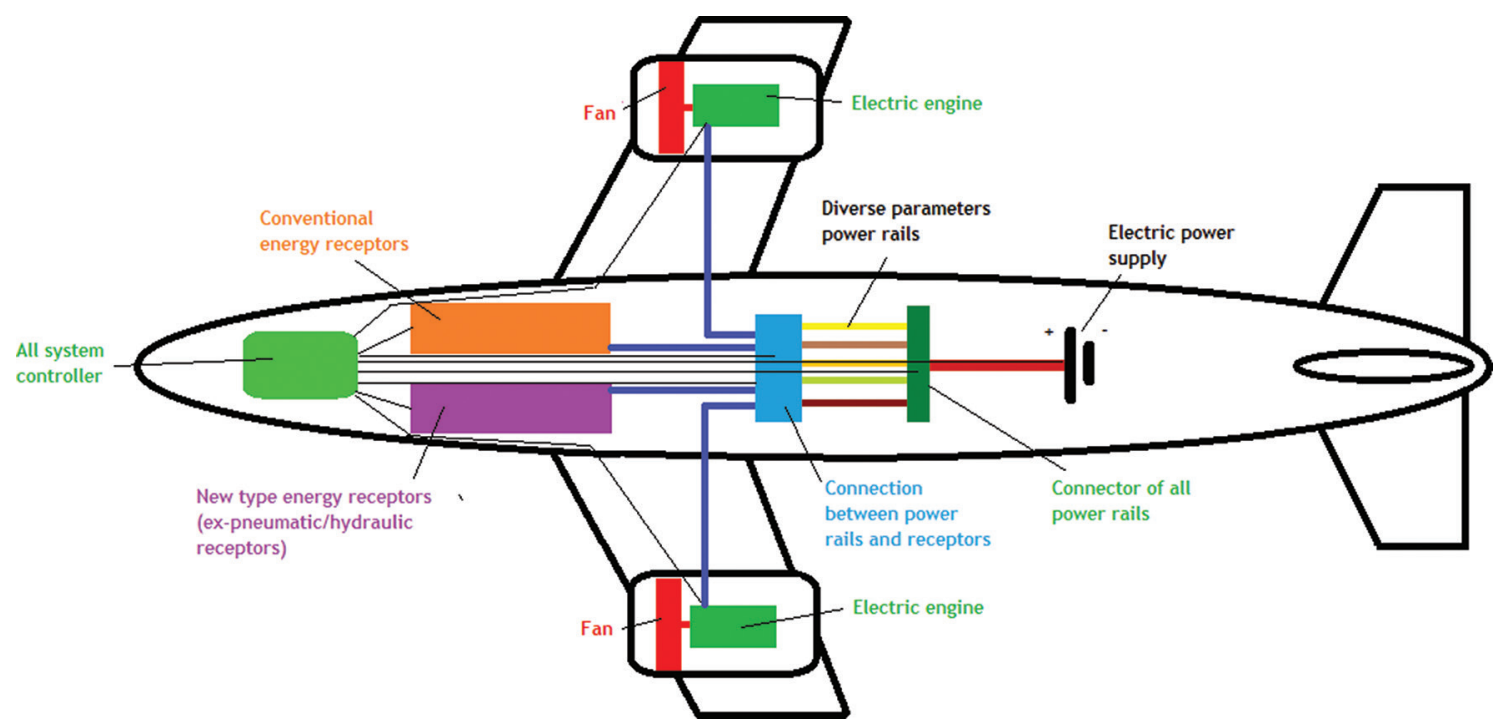

Fig. 4. Representation of an all-electric aircraft's construction. 


\section{The evolution of electrical aircraft}

Analysing the construction of an all-electric aircraft, we notice that the two structural elements that make an allelectric flight possible are the electric engine and the electric power supply. To imagine the electric power needed for an all-electric aircraft, we may cite the conventional engine CFM56 (CFM International) used in Airbus A320. This engine generates thrust, for which a power of $40 \mathrm{MW}$ is needed (Figure 5) (Bozhko et al., 2018). It means that in an all-electric jet engine, in which the impeller is powered by an electric engine, this electric engine will have to deliver this amount of power.

Modern electric engines generating this order of power exist, but they are very heavy and dimensionally incompatible with the sizes of conventional turbofan jet engines (Gieras, 2008). For example, the electric engine produced by Northrop Grumman Corporation, which generates the power of $36.5 \mathrm{MW}$, has a weight of 75 metric tonnes (Figure 6) (Roque et al., 2017).

The conventional CFM56 turbofan jet engine producing similar power weighs only 2.3 metric tonnes (according to the European Union Aviation Safety Agency [EASA] data sheet for the engine). It is important to note, on the basis of the given example, that the conventional drive is characterised by a mass-power ratio of about $58 \mathrm{~kg} / \mathrm{MW}$. In contrast, for electric drive with a similar power, this ratio is about $2,055 \mathrm{~kg} / \mathrm{MW}$. It follows that for power propulsion units with a capacity of tens of megawatts, the weight of the electric engines is about 35 times greater than for conventional jet engine. The ensuing problem of a too powerful electric engine results in not only the problem of

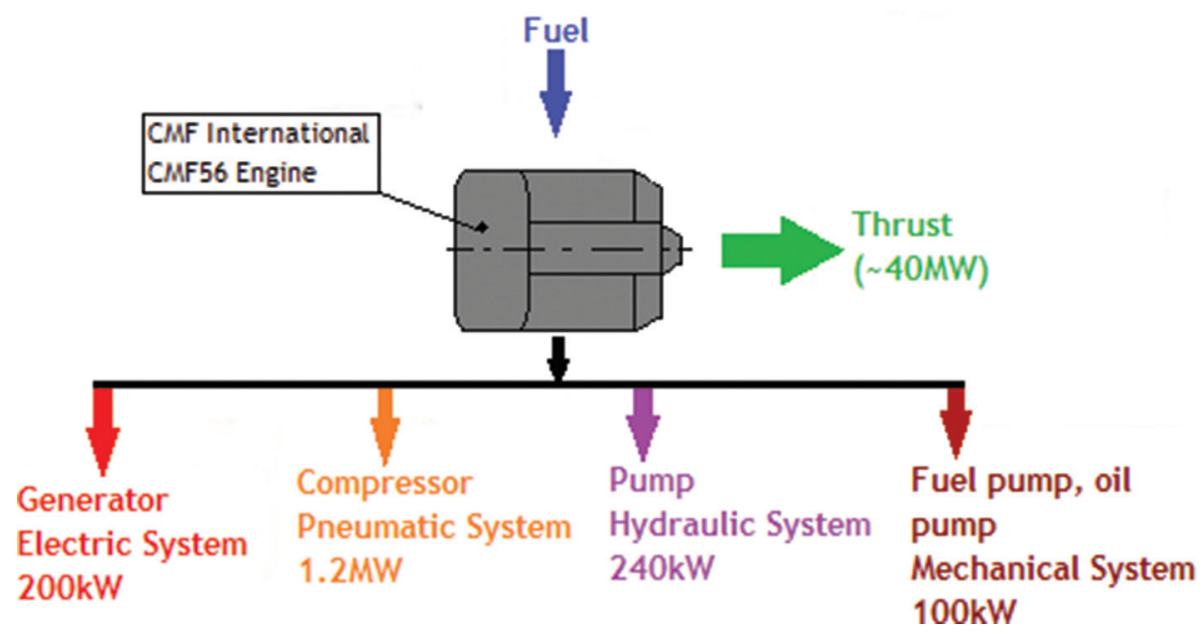

Fig. 5. The distribution of power generated by the engine of the passenger aircraft Airbus A320 (CFM56 engine, manufactured by CFM International)

\section{Copper motor}

$36.5 \mathrm{MW}, 120 \mathrm{rpm}, 6.6 \mathrm{KV}$

180-250 metric tonnes
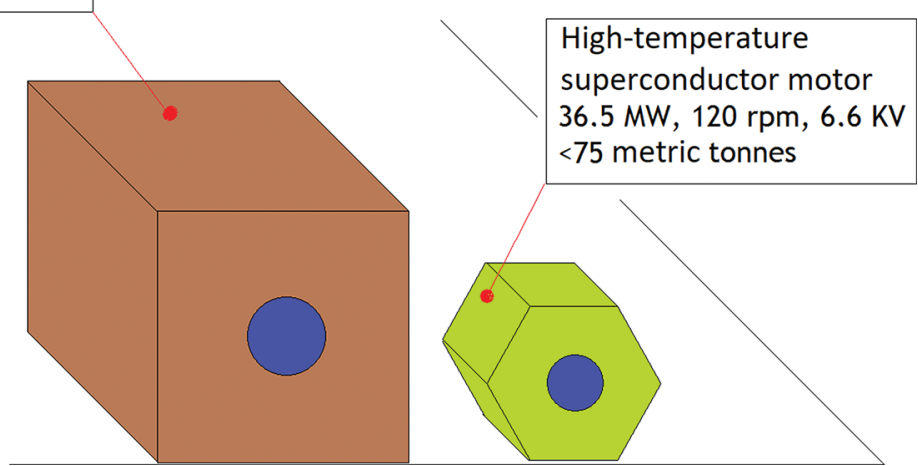

Fig. 6. Electric engine of power $36.5 \mathrm{MW}$ (Northrop Grumman Corporation). 
building an electric engine with satisfactory parameters but also circumventing the problem of the electric power source. It means that with the prevalent technology, the construction of an all-electric aircraft is not efficacious. The domains that can help develop the all-electric aircraft are research on superconducting materials (reducing the electrical engine's weight) and research on efficient ways to store or generate greater amount of electric energy.

The weight of a conventional aircraft converted into an electric aircraft is affected by the mass of the new electrical equipment and by the mass of equipment that will be removed. In addition, the mass of the aircraft is also influenced by the mass of the elements that may be replaced with new elements, made using modern and light materials. Thus, the mass of the new aircraft will be influenced by factors such as the size of the aircraft, the range and the modernity of its structure. At the design stage, it is not possible to accurately estimate the weight of the electric aircraft. Only the first constructions will be able to indicate this trend.

In the context of the development of actual all-electric passenger aircraft, the intensive development of totally electrical-powered drones and the work of some organisations on the development of all-electric aircraft may be noted, e.g. the Airbus company's creation of the E-Fan, a small all-electric two-passenger aircraft. In the near future, the development of all-electric aircraft will start with light aircraft, working on the principle of a hybrid between a conventional aircraft and an electric aircraft.

\section{Case study}

\subsection{Example of the PZL 104 Wilga 35}

A preliminary study of the conversion of a small airplane PLZ 104 Wilga 35 to an all-electric aircraft was done. In this study, the technical parameters of the aircraft were taken from the EASA type certificate data sheet and from the type acceptance report TAR 99/18 PZL-104 Wilga 35A. The technical parameters of the aircraft engine PZL Al-14RA were extracted from the type certification of this engine. At the beginning, the thrust generated by the original radial piston engine was estimated. The original engine (PZL Al-14RA) has the power of about $194 \mathrm{~kW}$, the maximum aircraft speed is about $200 \mathrm{~km} / \mathrm{h}$ and the aircraft's maximum altitude is $4,000 \mathrm{~m}$. The propeller efficiency is estimated to be about $85 \%$. These parameters permitted the estimation of the generated thrust of the original drive unit, which is about $3.00 \mathrm{kN}$ :

$$
T_{\max }=\frac{\eta_{\mathrm{p}} N}{V_{\max }},
$$

where

- $T_{\max }$ - estimated thrust generated by the original radial engine $[\mathrm{kN}]$;

- $\eta_{\mathrm{p}}$ - estimated efficiency of the propeller [\%];

- $N$ - power of the original radial engine [kW]; and

- $V_{\text {max }}$ - maximal speed of the aircraft [m/s].

The data used were as follows:

- $\eta_{\mathrm{p}}=0.85$

- $N=194 \mathrm{~kW}$

- $V_{\text {max }}=200 \mathrm{~km} / \mathrm{h}=55.55 \mathrm{~m} / \mathrm{s}$.

Then,

$$
\begin{aligned}
T_{\text {max }} & =\frac{0.85 \times 194}{55.55} \\
T_{\text {max }} & =2.97 \mathrm{kN} \\
T_{\text {max }} & \approx 3.00 \mathrm{kN}
\end{aligned}
$$


This value is obtained by simple calculation, without the knowledge of aircraft's flight parameters. The altitude at which it is possible to fly with maximum velocity is not known. For the project's needs, it was assumed that the aircraft is able to fly with maximum velocity $(200 \mathrm{~km} / \mathrm{h})$, with maximum thrust $(3.00 \mathrm{kN})$ and at the maximum altitude $(4,000 \mathrm{~m})$. These boundary parameters show that the calculated fan power for this airplane to fly will be greater than really needed. In the primary version of the project of energy conversion, it was decided to use two all-electric jet engines. It means that a single electric jet engine has to generate a thrust of approximately $1.50 \mathrm{kN}$. According to the simulation calculations, the needed fan power of a single electric jet engine is presented in Figure 7.

The fan power of a single electric jet engine was calculated according to the project earlier data. For a fan with an efficiency of $100 \%$, the needed engine power is $113.940 \mathrm{~kW}$. Finally, estimating the fan efficiency at $80 \%$, the engine power needed is estimated to be about $142.43 \mathrm{~kW}$, as follows:

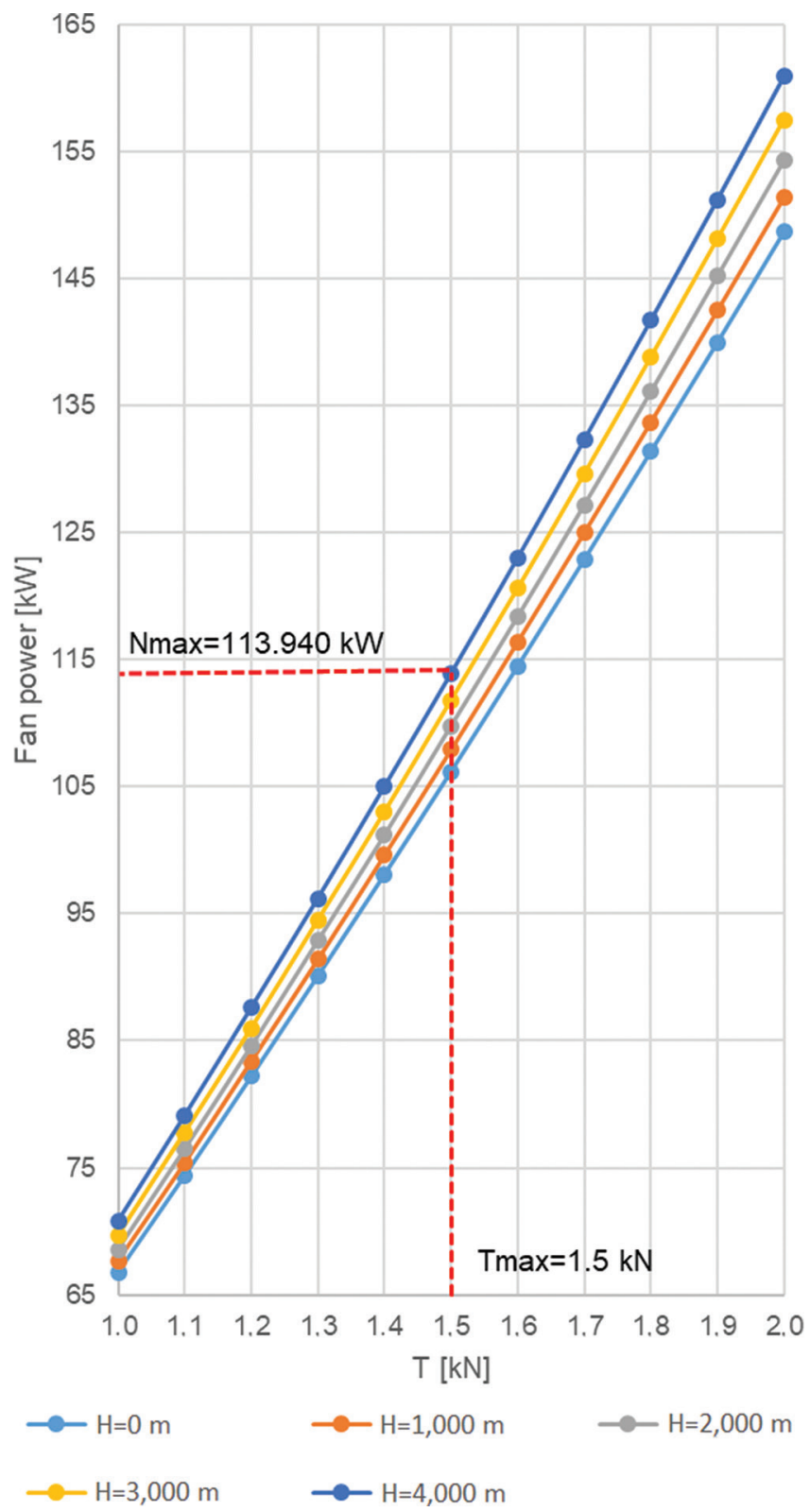

Fig. 7. The needed fan power as a function of the generated thrust and the flight altitude for a maximal speed $V=200 \mathrm{~km} / \mathrm{h}$. 


$$
N_{\text {engine }}=\frac{N_{\text {fan }}}{\eta_{\text {fan }}},
$$

where

- $N_{\text {engine }}-$ mechanical power of the electric engine $[\mathrm{kW}]$;

- $N_{\text {fan }}$ - ideal fan power needed [kW]; and

- $\eta_{\text {fan }}-$ fan efficiency [\%].

The data used were as follows:

- $N_{\mathrm{fan}}=113.940 \mathrm{~kW}$;

- $\eta_{\text {fan }}=0.80$.

Then,

$$
\begin{aligned}
& N_{\text {engine }}=\frac{113.940}{0.80} \\
& N_{\text {engine }}=142.425 \mathrm{~kW} .
\end{aligned}
$$

The needed power of single electric engine is estimated to be about $145 \mathrm{~kW}$ (the summary electric power is about $290 \mathrm{~kW}$, which is effectively greater than the power of the original radial engine). To generate this power, two electric engines - HVH 250 HT high flow cooling - will be used, produced by Remi International (acquired by BorgWarner since 2015, which location is 3850 Hamlin Rd, Auburn Hills, Ml 48326 United States of America) with power of $150 \mathrm{~kW}$ and efficiency of $93 \%$ (according to the producer's data sheet). The needed electric power to run a single electric engine is $153.145 \mathrm{~kW}$ :

$$
N_{\text {electricity(engine) }}=\frac{N_{\text {engine }}}{\eta_{\text {engine }}},
$$

where

- $N_{\text {electricity(engine) }}$ - electric power needed to power a single electric jet engine [kW];

- $N_{\text {engine }}-$ mechanical power needed from the electric engine [kW];

- $\eta_{\text {engine }}$ - engine efficiency [\%].

The data used were as follows:

- $N_{\text {engine }}=142.425 \mathrm{~kW}$;

- $\eta_{\text {engine }}=0.93$.

Then,

$$
\begin{aligned}
& N_{\text {electricity(engine) }}=\frac{142.425}{0.93} \\
& N_{\text {electricity(engine) }}=153.145 \mathrm{~kW} .
\end{aligned}
$$

The calculated electric power is the power needed to be sent to a single electric jet engine. Considering that the aircraft will be equipped with two jet engines, and considering that all the other on-board equipment use electrical 
energy (approximately $5 \%$ of the drive unit's power), the total electric power needed to be generated by the onboard electrical power source is $321.604 \mathrm{~kW}$ :

$$
N_{\text {total elec. }}=z \cdot N_{\text {electricity(engine) }}\left(1+\frac{p_{\text {equipment }}}{100}\right),
$$

where

- $\quad N_{\text {total elec. }}$ - the electrical power needed to be generated by the on-board power source [kW];

- $\quad z$ - number of electric jet engines on board [-];

- $\quad N_{\text {electricity(engine) }}$ - electric power needed to power just a single electric jet engine [kW];

- $p_{\text {equipment }}-$ percentage of electric power needed to power the other on-board equipment [\%],

The following data were used:

- $z=2$;

- $N_{\text {electricity(engine) }}=153.145 \mathrm{~kW}$;

- $p_{\text {equipment }}=5 \%$.

Then,

$$
\begin{aligned}
& N_{\text {total elec. }}=2 \times 153.145\left(1+\frac{5}{100}\right) \\
& N_{\text {total elec. }}=321.604 \mathrm{~kW}
\end{aligned}
$$

The time for a single flight is estimated by the knowledge of aircraft range and the travel velocity. The work period of the on-board power source is about $5.332 \mathrm{~h}$ :

$$
t=I+\frac{L}{V}
$$

where

- $t$ - work period of the electric power source [h];

- $\quad I-1 \mathrm{~h}$ is added to the travel time to consider the ground manoeuvres and a time reserve [h];

- $L$ - range of the aircraft [km];

- $\quad V$ - flying velocity of the aircraft $[\mathrm{km} / \mathrm{h}]$.

The following data were used:

- $L=680 \mathrm{~km}$;

- $V=157 \mathrm{~km} / \mathrm{h}$.

Then,

$$
t=1+\frac{680}{157}=5.332 \mathrm{~h} .
$$

Previous research (Mueller et al., 2018) has shown that the use of fuel cells is an interesting option; the weight of such power supply (including the fuel) would be even smaller than the weight of the batteries. The evolution 
of fuel cells is expected in the near future. Hence, in this case study, fuel cell power supply was preliminarily selected. With the knowledge of (i) the electrical power needed to be generated by the on-board power source and (ii) the work period of the aircraft for a single flight, it is possible to preliminarily design the power source, based on various research reports and projects on fuel cells (Burke, 2003; Cable et al., 2009; Jaroszewicz, 2017). The power source is SOFC. According to the calculation, the parameters of this SOFC power source are presented in Table 1.

Based on the research of the National Aeronautics and Space Administration (NASA) on electricity storage (Burke, 2003), SOFCs have a power density around $1,000 \mathrm{~W} / \mathrm{kg}$. This means that for generating a power of about $330 \mathrm{~kW}$, the mass of the fuel cell stack needs to be about $330 \mathrm{~kg}$. Given that about $90 \mathrm{~kg}$ of hydrogen is necessary to power fuel cells, for the duration of the flight, it may be determined in the first estimate that the mass of the fuel cell-based power supply system will be approximately $420 \mathrm{~kg}$. From the same NASA research, is shown that for the more-effective batteries (Li-ion high-energy ones), the maximum power density is about 1,000 W/kg, with an energy density of about $170 \mathrm{Wh} / \mathrm{kg}$. For a power of about $330 \mathrm{~kW}$, due to the power density, the battery should weigh about $330 \mathrm{~kg}$. The energy demand from this battery should also be determined, which is approximately $1,759,560 \mathrm{Wh}$ $(330,000 \mathrm{~W} \times 5.332 \mathrm{~h})$, which means that, due to the energy density, the weight of this battery will be approximately $10,350 \mathrm{~kg}$. This means that using batteries, the weight of the power supply system will be about 10 metric tonnes, which significantly exceeds the weight of the fuel cells, including the weight of hydrogen $(420 \mathrm{~kg})$, but also greater than the weight of the entire aircraft $(900 \mathrm{~kg})$. This weight-related advantage of using fuel cells, instead of batteries, shows the supremacy of the fuel cells.

Finally, the knowledge of all these parameters allows comparison of the weight of the aircraft before and after the conversion (Table 2). It is important to note that the performances of the aircraft have not changed.

The aircraft PZL 104 Wilga 35 has been designed in the second part of the 20th century; therefore, using modern aircraft materials to build this aircraft, a reduction of $25 \%$ in the aircraft weight is possible. To estimate the weight loss, the mass of the engine $(200 \mathrm{~kg})$ was deducted from the aircraft's total weight: $(900-200) \times 0.25=175 \mathrm{~kg}$.

Table 1. The SOFC power supply parameters.

\begin{tabular}{lc}
\hline Parameters & Values \\
\hline \hline Real SOFC power & $327,726 \mathrm{~W}$ \\
Real SOFC output electric voltage & $650.25 \mathrm{~V}$ \\
Real SOFC output electric amperage & $504 \mathrm{~A}$ \\
Quantity of SOFC in serial connection in single SOFC column & 867 \\
Quantity of SOFC columns in parallel connection & 9 \\
Quantity of SOFCs & 7,803 \\
Air mass flow & $0.156 \mathrm{~kg} / \mathrm{s}$ \\
Hydrogen mass flow & $4.588 \times 10^{-3} \mathrm{~kg} / \mathrm{s}$ \\
Water vapour mass flow & $0.041 \mathrm{~kg} / \mathrm{s}$ \\
On-board hydrogen weight & $\approx 90 \mathrm{~kg}$ \\
SOFC power source weight & $\approx 330 \mathrm{~kg}$ \\
\hline
\end{tabular}

Table 2. The mass change because of the conversion to an 'all-electric aircraft',

\begin{tabular}{lccc}
\hline & & & \multicolumn{2}{c}{ Added mass } \\
\cline { 1 - 2 } Element & Mass, $\mathrm{kg}$ & Element & Mass, $\mathrm{kg}$ \\
\hline \hline Engine & 200 & Engine $\times 2$ & 136 \\
Fuel & 155 & SOFCs & 330 \\
Structure & 175 & Hydrogen & 90 \\
Sum & 530 & Sum & 556 \\
Mass difference, $\mathrm{kg}:$ & & & +26 \\
\hline
\end{tabular}




\subsection{Example of the Boeing 787 Dreamliner}

After the analysis of a small aircraft (PZL 104 Wilga 35), an analysis of the ability to develop an all-electric jet engine for a Boeing B787 with two GEnx turbofan jet engines was also performed. According to the data sheets, the maximum thrust of one drive is about $320 \mathrm{kN}$. In the simulations, as detailed earlier, the structural characteristics were obtained (Figure 8), showing the power necessary to drive a single engine as a function of the required thrust for different flight ceilings.

Assuming that at a ceiling of $13.1 \mathrm{~km}$, the drive unit generates about $75 \%$ of the maximum thrust, $240 \mathrm{kN}$, it was estimated that the necessary engine power will be about $100 \mathrm{MW}$. Previously, based on Northrop Grumman Corporation's electric engine, it was determined that the ratio of the weight of the electric engine to the generated power is about 2,050 kg/MW. Using this ratio in this analysis, it was established that an electric engine with a power of about $100 \mathrm{MW}$ would weigh about $205,000 \mathrm{~kg}$. The conventional GEnx drive unit weighs around 5,800 kg. It follows that the use of an electric propulsion unit instead of a conventional jet engine would result in an increase of weight by about 35 times. On this basis, the infeasibility of building a completely electric drive unit for large passenger aircraft was seen. As part of this analysis, further consideration of the possibility of building large passenger aircraft is pointless.

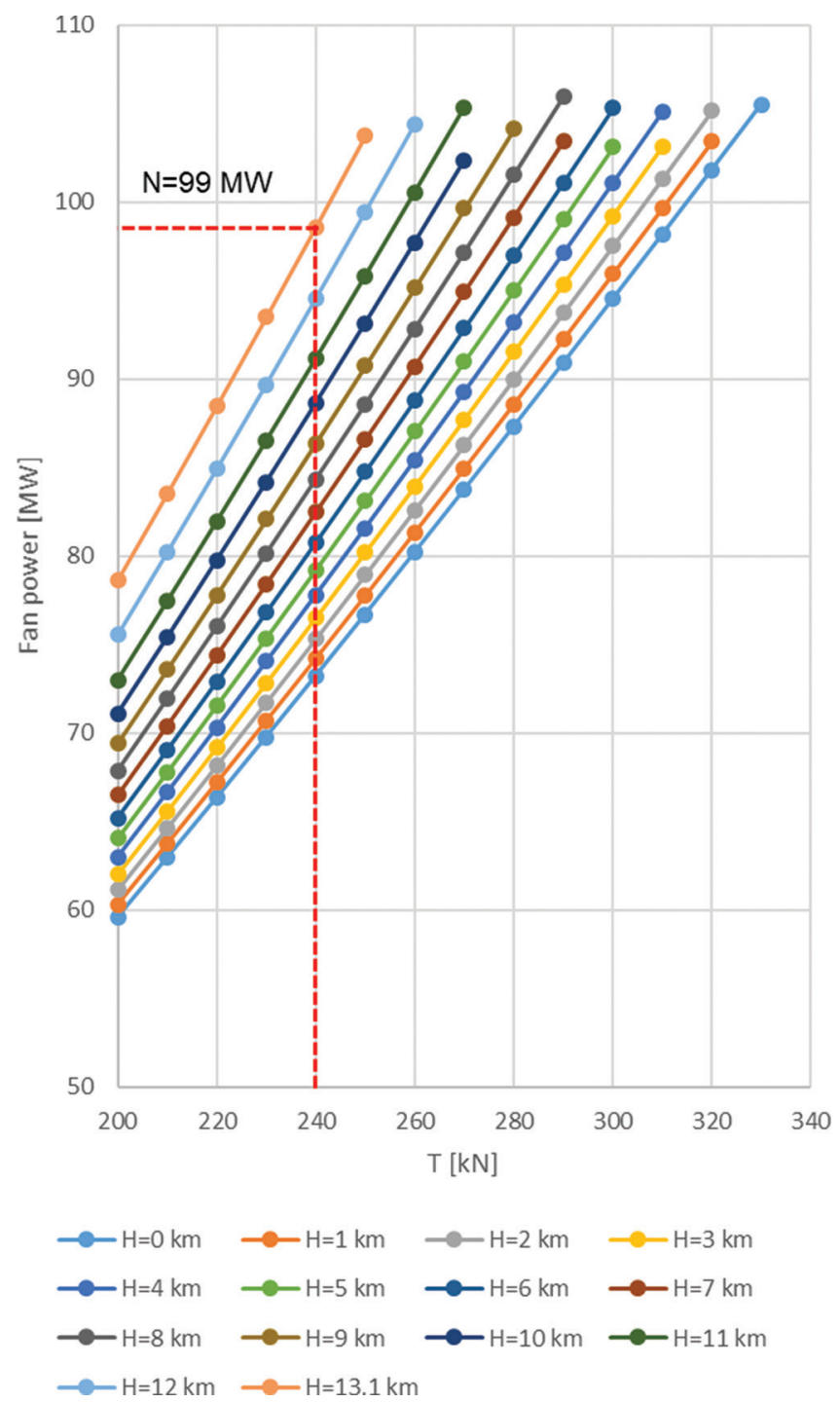

Fig. 8. The fan power needed as a function of the generated thrust and the flight altitude for the cruising speed $V=900 \mathrm{~km} / \mathrm{h}$. 


\subsection{Case study conclusion}

To establish the possibility of constructing a small electric aircraft, an analysis of the technical requirements for the aircraft PZL 104 Wilga 35 was performed. It is a $900 \mathrm{~kg}$ weight construction. On the basis of the calculations, the possibility of replacing the classic piston drive, weighing $200 \mathrm{~kg}$, by two smaller electric jet drives was demonstrated. Each of the electric motors weighs $68 \mathrm{~kg}$ (both together weigh $136 \mathrm{~kg}$ ). This means that, in this case, replacing the classic drive with an electric drive permits saving about $64 \mathrm{~kg}$. Going forward, it was supposed that the mass of the on-board equipment had not changed. The analysis also showed that the weight of the electric power supply unit, based on fuel cells and hydrogen, is approximately $420 \mathrm{~kg}$. In the original aircraft, the on-board source of energy was fuel, the weight of which is about $155 \mathrm{~kg}$. This means that as a result of the conversion of the on-board energy source, the mass of the aircraft will increase about $265 \mathrm{~kg}$. It follows from the above analysis that as the result of the conversion of an aircraft into the electric propulsion mode, the total weight gain of the aircraft, in this case, will be around $201 \mathrm{~kg}$. The weight of the empty aircraft before converting into electric drive was $900 \mathrm{~kg}$. Thus, the ratio of the mass of aircraft after conversion to the weight of aircraft before conversion is, in the first estimate, about 1.22 . The analysed aircraft is a construction made in the second half of the 20th century; hence, it may be supposed that it is possible to replace the aircraft's structural elements with modern composite materials, the use of which will allow for weight loss. In the analysis, a loss of $25 \%$ of the weight of the original structure was assumed, i.e. $175 \mathrm{~kg}$. Taking into consideration this possibility, the weight gain of the aircraft will not be $201 \mathrm{~kg}$, but only $26 \mathrm{~kg}$. Thus, it may be concluded that using modern design materials, it is possible to build small electric aircraft with comparable performances to those existing today.

Referring to the analysis carried out for large passenger aircraft, here, the Boeing 787 Dreamliner, it may be concluded that the replacement of conventional drive units by electric drives is associated with an increase of weight about 35 times. The conventional GEnx drive weighs about 5,800 kg, which means that the weight of the two turbofan drives (which are found in the conventional aircraft analysed) is approximately $11,600 \mathrm{~kg}$. This means that the weight of both electric motors alone would be about 410,000 kg. The maximum take-off mass of the B787 is approximately $215,000 \mathrm{~kg}$. Thus, it is not possible to use electric propulsion for large passenger aircraft.

From the above analyses, it seems to be possible to build small electric aircraft. It was also shown that it is currently not possible to build a large passenger aircraft. In addition, it may be concluded that the development of electric aircraft is very strongly linked to the development of both high-temperature superconducting materials (for the construction of electric engines) and fuel cells. Another problem linked with the development of electric aircraft may be the non-profitable nature of this kind of transport currently.

\section{Summary}

Following the analysis of the technical requirements for the construction of a fully electric passenger aircraft, it may be concluded that it is currently not possible to build a passenger aircraft with exemplary performances equalling that of the Boeing B787. The factor limiting the possibility of building this drive unit is the weight of the electric engine. Modern megawatt-rated electric engines are relatively heavy, and it would be impossible to use them for aircraft propulsion. Another element that would limit the development of a passenger aircraft is the on-board source of electric energy. Nevertheless, the analysis showed hypothetically that an electric drive unit could be built for a small passenger aircraft such as the PLZ 104 Wilga 35. Great hope for the development of electric aviation lies in the development and optimisation of modern electric engines in terms of weight and power. The development of high-temperature superconducting materials is an element that will contribute to this effort. Electric engines made of such materials would be lighter while maintaining same power. Research and development of fuel cells is also a desirable element for the development of electric aviation. Unfortunately, currently, the technology only permits the construction of small electric aircraft.

The reliability of this analysis is in line with the course of projects conducted by the Airbus Group. In 2011, a project was started, the result of which was a double-seated electric aircraft called 'E-Fan'. The aircraft has an electric drive and electrical equipment powered by on-board batteries (Li-ion). The prototype was flown on $11 \mathrm{March}$ 2014. On 10 July 2015, this aircraft became the first all-electric aircraft to fly across the English Channel. The next step was to start work on the hybrid aircraft "E-Fan X" in 2017, which is expected to fly in 2021. Another venture, sponsored by the same company, is to organise in 2021, electric-powered aircraft race, called 'Air Race E'. The 
Airbus Group contributes for the development of electric aviation, but at the moment, only small electric-powered aircraft are built.

The electric aircraft will be equipped with an electric drive unit. However, the use of electric propulsion necessitates the conversion of other on-board systems into electric power supply. Thus, the electric jet drive unit and all aircraft systems will be powered by electricity. In the analysis, fuel cells have been used as a source of electricity because they have consistent performance, need not be 'charged' and only generate heat and steam. As a result of the presence of other energy sources and receivers in a fully electric aircraft, it is also necessary to design a different type of power grid than that found in conventional aircraft.

As stated earlier, aviation is one of the main factors that affect the environment in which we live. Aviation generates chemical and acoustic pollution. Because of the concluded analysis, the possibility of building drive units for the smallest flying units has been demonstrated. This means that the process of 'moving' into electric aviation will start with small flying units, and with the development of technology, proceed to ever-larger aircraft. Therefore, a complete transition to electric aviation is not yet possible, but it will be probably feasible in the future. It is certain that the passage to all-electric aircraft will be done in few stages and over a long period.

\section{References}

Bozhko, S., Hill, C. and Yang, T. (2018). More electric aircraft: systems and modeling. In: Webster J. G. ed., Wiley Encyclopedia of Electrical and Electronics Engineering. Hoboken: John Wiley \& Sons, Inc. DOI: https://doi.org/10.1002/047134608X.W8367

Burke, K. A. (2003). Fuel cells for space science applications. NASA Glenn Research Center, Cleveland, Ohio. In: First International Energy Conversion Engineering Conference. Portsmouth, 17-21 August 2003.

Cable, T. L., Farmer, S. C., Eckel, A. J. and Setlock, J. A. (2009). Regenerative performance of the NASA symmetrical solid oxide fuel cell design. International Journal of Applied Ceramic Technology, 8(1), pp. 1-12.

Climate Change Authority. (2014). Light vehicle emissions standards for australia research report, <http://www.climatechangeauthority. gov.au/files/files/Light\%20Vehicle\%20Report/ Lightvehiclesreport.pdf> [available 02/07/2020].

Dzierżanowski, P., Kordziński, W., Łyżwiński, M., Otyś, J., Szczeciński, S. and Wiatrek, R. (1983). Aviation Drives - Turbine Jet Engines. Warsaw: Transport and Communication Publishers.

Eco-Healthy Child Care. (2016). Noise pollution, <https://cehn.org/wp-content/uploads/2015/12/ Noise_Pollution_9_16.pdf> [available 02/07/2020].

Gieras, J. F. (2008). Advancements in Electric Machines. Berlin-Heidelberg: Springer, pp. 247-249.

Jaroszewicz, A. (2017). Analysis of the possibility of use of a solid oxide fuel cell as an auxiliary power unit for modern passenger aircraft. Scientific Letters of
Rzeszow University of Technology - Mechanics, 89(1), pp. 45-62.

Maré, J. C. and Fu J. (2017). Review on signal-by-wire and power-by-wire actuation for more electric aircraft. Chinese Journal of Aeronautics, 30(3), pp. 857-870.

Mueller, J.-K., Bensmann A., Bensmann B., Fischer T., Kadyk T., Narjes G., Kauth F., Ponick B., Seume J. R., Krewer, U., Hanke-Rauschenbach, R. and Mertens, A. (2018). Design considerations for the electrical power supply of future civil aircraft with active high-lift systems. Energies, 11(1), pp. 1-21.

Roque, A., Sousa, D. M., Fernão Pires, V. and Margato, E. (2017). Superconductivity and their applications. In: International Conference on Renewable Energies and Power Quality. Malaga, 4-6 April 2017.

Tariq, M., Maswood, A. I., Gajanayake, C. J. and Gupta, A. K. (2017). Aircraft batteries: current trend towards more electric aircraft. IET Electrical Systems in Transportation, 7(2), pp. 93-103.

Wolkiewicz, M. and Skowron, M. (2017). Diagnostic system for induction motor stator winding faults based on axial flux. Power Electronics and Drives, 2(2), pp. 137-150.

Yang, Z., Qu, J., Yingchuan, M.A. and Shi, X. (2015). Modeling and simulation of power distribution system in more electric aircraft. Journal of Electrical and Computer Engineering, 2015(8), pp. 1-7. 